\title{
High-Temperature Oxidation of Fe-12Cr-0.3C-4Mn-(13-15)Cu Composite Alloys
}

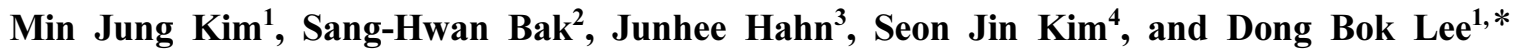 \\ ${ }^{1}$ School of Advanced Materials Science and Engineering, Sungkyunkwan University, Suwon 16419, Republic of Korea \\ ${ }^{2}$ Advanced Materials and Processing Center, Institute for Advanced Engineering (IAE), Yongin 17186, Republic of Korea \\ ${ }^{3}$ Center for Energy Materials Metrology, Korea Research Institute of Standards and Science, Daejon 34113, Republic of Korea \\ ${ }^{4}$ Division of Materials Science and Engineering, Hanyang University, Seoul 04763, Republic of Korea
}

\begin{abstract}
Alloys of Fe-12Cr-0.3C-4Mn-(13, 14, 15)Cu (wt\%) were cast using an induction furnace. They were structurally heterogeneous composites that consisted of a relatively stiff a-Fe matrix and a soft $(\mathrm{Cu}, \mathrm{Mn})$-rich secondary phase. They were developed as self-lubricating, wear-resistant metals. Since the formation of oxides plays an important role in wear, understanding the oxidation behavior of two-phase, multi-component composites is of practical interest. This study was undertaken to understand the effect of varying $\mathrm{Cu}$ concentration on the formation of oxide scales. When the concentration of $\mathrm{Cu}$ in the alloys was increased to 13,14 , and $15 \mathrm{wt} \%$, the volume fraction of the secondary phase also increased from $10.3,11.2$, and $13.3 \mathrm{vol} \%$. When oxidized at $700{ }^{\circ} \mathrm{C}$ for $30 \mathrm{~h}$, the secondary phase preferentially oxidized to oxide nodules due to $\mathrm{Cu}$ and $\mathrm{Mn}$, which could not form a protective scale. The matrix was uniformly oxidized, forming a thin surface scale, due mainly to oxidation-resistant $\mathrm{Cr}$ in the matrix. When oxidized at $800-900{ }^{\circ} \mathrm{C}$ for $30 \mathrm{~h}$, not only the secondary phase but also the $a$-Fe matrix oxidized rapidly, because of the increased reaction and diffusion rates, resulting in the formation of thick, bi-layered oxide scales. An Fe-rich outer scale was formed by the outward diffusion of $\mathrm{Fe}, \mathrm{Cr}, \mathrm{Mn}$, and $\mathrm{Cu}$, while a $\mathrm{Cr}$-rich inner scale was formed by the inward diffusion of oxygen. $\mathrm{Mn}$ and $\mathrm{Cu}$ were rather uniformly distributed in the outer and inner oxide scales. The oxidation rates increased with increasing amounts of $\mathrm{Cu}$, and significantly more with increasing temperature.
\end{abstract}

(Received April 18, 2019; Accepted June 28, 2019)

Keywords: composite, alloy steel, copper, oxidation, oxidation scale

\section{INTRODUCTION}

Self-lubricating metals are used in bearings, automotive components, pumps, motors, drilling and grinding machines because they provide economical, ecological benefits and allow simplified designs [1,2]. They do not require oil or grease because the lubricants are already incorporated in the metals, which means they are lubricated for their lifetime. They are maintenance-free, and ideally suited for use in difficult working environments, high temperature applications, etc. In one type, strong cast bronze is embedded with a solid lubricant in the form of powdered graphite [3]. However, bronze consists primarily of costly $\mathrm{Cu}$ combined with 12 $12.5 \% \mathrm{Sn}$. In order to replace bronze with more cost-effective

- 김민정·김선진·이동복: 교수, 박상환·한준희: 연구원

*Corresponding Author: Dong Bok Lee

[Tel: +82-31-290-7355, E-mail: dlee@skku.ac.kr]

Copyright (C) The Korean Institute of Metals and Materials metals, and produce self-lubricating metals that can be employed in heavy load, low speed, and high-temperature applications, Fe-based cast self-lubricating composites, consisting of a relatively stiff matrix and soft secondary phase, have been introduced [4,5]. One example is cast composite alloys of $\mathrm{Fe}-12 \% \mathrm{Cr}-0.3 \% \mathrm{C}-4 \% \mathrm{Mn}-(13-15) \% \mathrm{Cu}$, which are comprised of an iron matrix with $\mathrm{Cu}$-rich secondary particles [6,7]. By increasing the $\mathrm{Cu}$ concentration, the volume fraction of the $\mathrm{Cu}$-rich secondary particles, and overall wear resistance are increased. Protective tribofilms consisting of $\mathrm{CuO}, \mathrm{Cu}_{2} \mathrm{O}, \mathrm{Fe}_{2} \mathrm{O}_{3}$ and $\mathrm{Fe}_{3} \mathrm{O}_{4}$ are formed during dry sliding wear.

Wear inevitably occurs with oxidation, so controlling oxides is important in efforts to obtain low wear rates and friction coefficients $[8,9]$. Because most engineering alloys are multi-phase, it is of practical interest to determine how two-phase, multi-component composites oxidize at high temperatures. 
Table 1. Chemical compositions of Fe-12Cr-0.3C-4Mn-(13, 14, 15)Cu alloys (wt\%)

\begin{tabular}{ccccccc}
\hline Nominal composition & $\mathrm{Fe}$ & $\mathrm{Cr}$ & $\mathrm{C}$ & $\mathrm{Mn}$ & $\mathrm{Cu}$ \\
\hline Fe-12Cr-0.3C-4Mn-13Cu & Bal. & 12.21 & 0.281 & 4.212 & 12.89 \\
\hline Fe-12Cr-0.3C-4Mn-14Cu & Bal. & 11.89 & 0.288 & 4.132 & 13.78 \\
\hline Fe-12Cr-0.3C-4Mn-15Cu & Bal. & 12.41 & 0.279 & 4.038 & 14.84 \\
\hline
\end{tabular}

Accordingly, this study examined the oxidation behavior of Fe- $12 \% \mathrm{Cr}-0.3 \% \mathrm{C}-4 \% \mathrm{Mn}-(13-15) \% \mathrm{Cu}$ cast composite alloys at high temperatures. The volume fraction of $\mathrm{Cu}$-rich phases, the oxidation kinetics, and the morphology of the oxide scales are discussed as a function of the $\mathrm{Cu}$ concentration.

\section{EXPERIMENTAL}

Lumps of electrolytic $\mathrm{Fe}, \mathrm{Cr}, \mathrm{Mn}$, and oxygen-free high thermal conductivity $(\mathrm{OFHC}) \mathrm{Cu}$, and graphite powder were melted in an alumina crucible using an induction furnace at a frequency of $24 \mathrm{kHz}$ in an argon atmosphere, and were then poured into a water cooled copper mold to prepare $\mathrm{Fe}-12 \mathrm{Cr}$ $0.3 \mathrm{C}-4 \mathrm{Mn}-(13,14,15) \mathrm{Cu}$ composite alloys. Table 1 lists the compositions that were analyzed using an optical emission spectrometer. The prepared alloys were cut into coupons $5 \times 10 \times 10 \mathrm{~mm}^{3}$ in size, ground to a 1000 grit $\mathrm{SiC}$ finish, degreased with acetone and alcohol, and oxidized at 700, 800 , and $900{ }^{\circ} \mathrm{C}$ in atmospheric air for $5-50 \mathrm{~h}$ using a thermogravimetric analyzer. They were inspected by an optical microscope, a field-emission scanning electron microscope (SEM) equipped with an energy dispersive spectrometer (EDS), an electron probe microanalyzer (EPMA), a high-power X-ray diffractometer (XRD) with $\mathrm{Cu}$ $\mathrm{K} \alpha$ radiation at $40 \mathrm{kV}$ and $100 \mathrm{~mA}$, and an X-ray photoelectron spectrometer (XPS).

\section{RESULTS AND DISCUSSION}

The optical microstructures of the Fe-12Cr-0.3C-4Mn-(13, $14,15) \mathrm{Cu}$ alloys are shown in Fig. 1. Round secondary particles of various sizes are randomly distributed in the $\alpha$-Fe matrix. Their average volume fractions, which were evaluated using an image analyzer, were 10.3, 11.2, and 13.3 vol $\%$ for $13 \mathrm{Cu}, 14 \mathrm{Cu}$ and $15 \mathrm{Cu}$ alloys, respectively. In the $13 \mathrm{Cu}$ alloy, the average concentration of the matrix was $70.1 \mathrm{Fe}-14.9 \mathrm{Cr}-3.7 \mathrm{Mn}-11.3 \mathrm{Cu}$ (at $\%)$, while that of the (a)

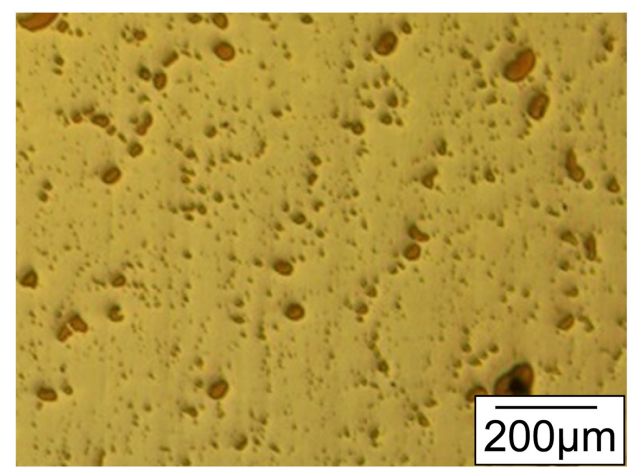

(b)

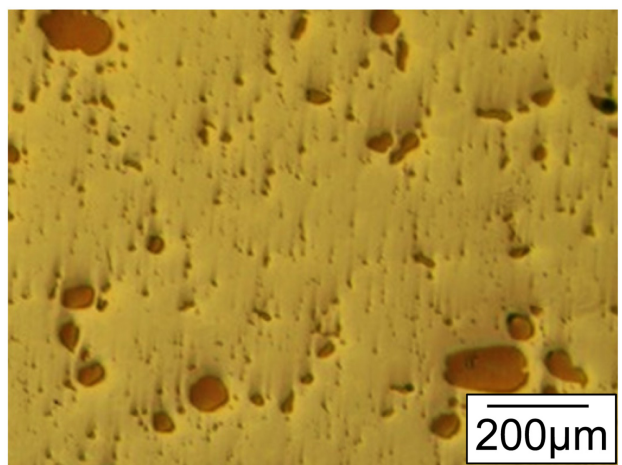

(c)

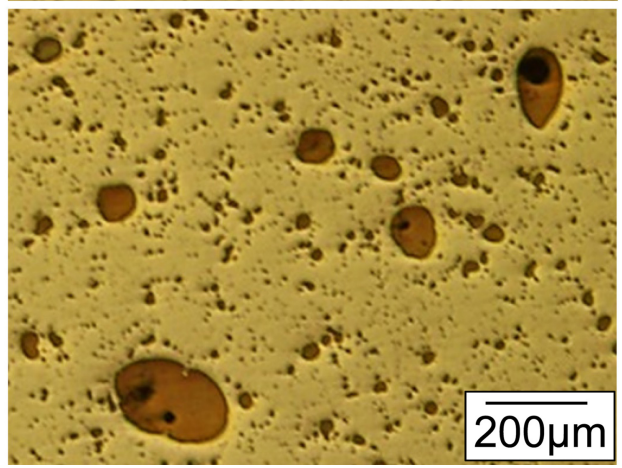

Fig. 1. Optical microstructures of (a) Fe-12Cr-0.3C-4Mn-13Cu, (b) $\mathrm{Fe}-12 \mathrm{Cr}-0.3 \mathrm{C}-4 \mathrm{Mn}-14 \mathrm{Cu}$, and (c) Fe-12Cr-0.3C-4Mn-15Cu alloys.

secondary phase was $84.5 \mathrm{Cu}-9.9 \mathrm{Mn}-4.7 \mathrm{Fe}-0.9 \mathrm{Cr}$ (at $\%$, according to the SEM/EDS analysis. The results indicated that the matrix and secondary phase were $(\mathrm{Fe}, \mathrm{Cr})-$ and $(\mathrm{Cu}$, Mn)-rich, respectively.

The oxidation kinetics of Fe-12Cr-0.3C-4Mn-(13, 14, 15) $\mathrm{Cu}$ alloys are depicted in Fig. 2. At $700{ }^{\circ} \mathrm{C}$, the $(13,14) \mathrm{Cu}$ alloys oxidized quite slowly, while the $15 \mathrm{Cu}$ alloy suffered 


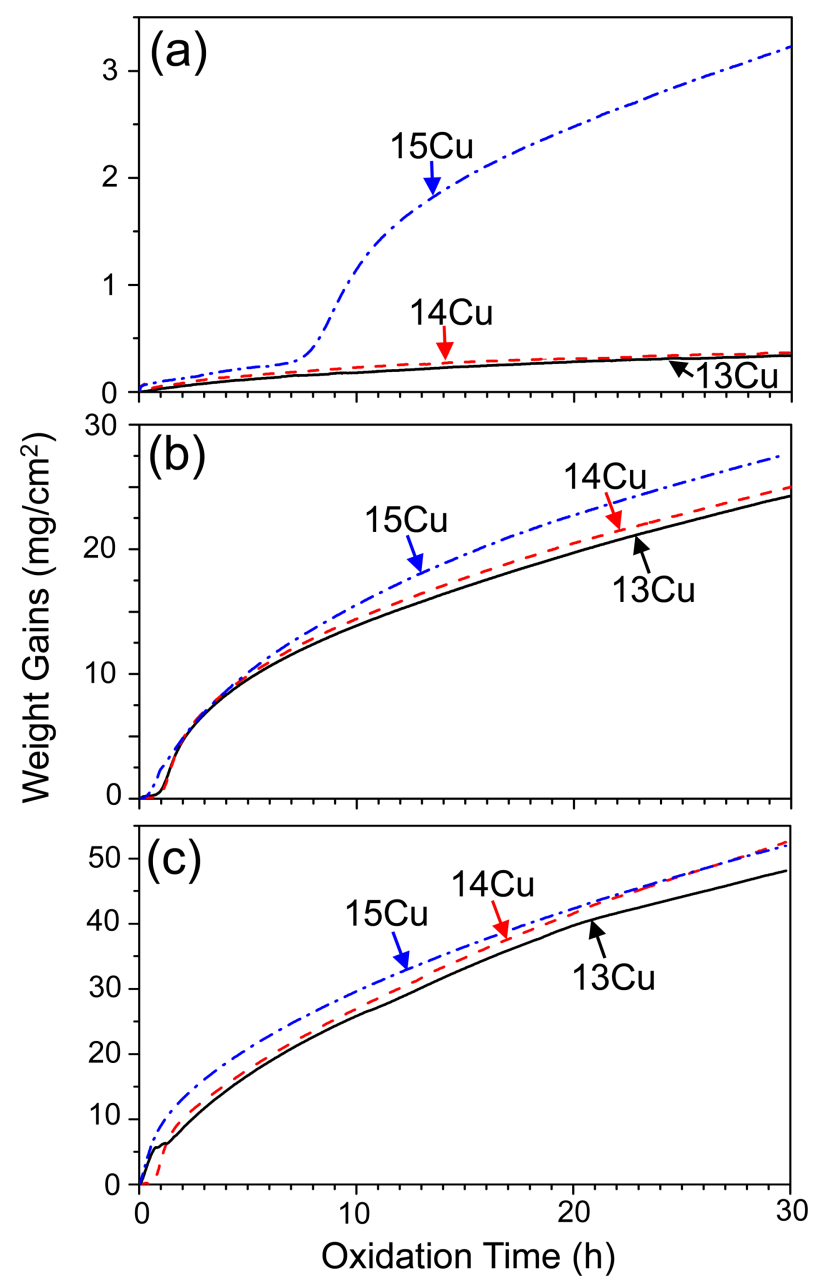

Fig. 2. Weight gain versus oxidation time curves of $\mathrm{Fe}-12 \mathrm{Cr}-0.3 \mathrm{C}$ $4 \mathrm{Mn}-(13,14,15) \mathrm{Cu}$ alloys at (a) $700{ }^{\circ} \mathrm{C}$, (b) $800{ }^{\circ} \mathrm{C}$, and (c) $900{ }^{\circ} \mathrm{C}$

breakaway oxidation after $7 \mathrm{~h}$. At $800{ }^{\circ} \mathrm{C}$, after the initial incubation period all the alloys oxidized rapidly with large weight gains. At $900{ }^{\circ} \mathrm{C}$, they oxidized excessively fast, displaying negligible oxidation resistance. Clearly, the alloys oxidized progressively faster with increasing oxidation temperature and $\mathrm{Cu}$ concentration. Of these, the effect of temperature was larger than that of $\mathrm{Cu}$ content.

The Ellingham diagram of oxides that can form on $\mathrm{Fe}-$ 12Cr-0.3C-4Mn-(13, 14, 15) Cu alloys is shown in Fig. 3 [10]. Oxide stability increases in the order of $\mathrm{Cu}_{2} \mathrm{O}, \mathrm{FeO}$, $\mathrm{Cr}_{2} \mathrm{O}_{3}$, and $\mathrm{MnO}$. The secondary phase was rich in both the most noble $\mathrm{Cu}$ and the most active $\mathrm{Mn}$, while the matrix was rich in $\mathrm{Fe}$ and $\mathrm{Cr}$, both of which have intermediate oxygen affinities in their standard state.

From the oxidation curves displayed in Fig. 2, the

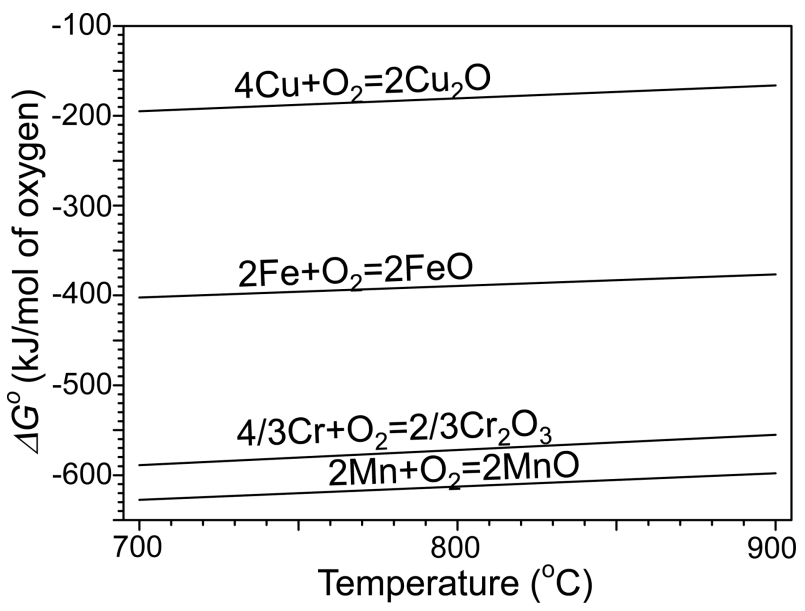

Fig. 3. Ellingham diagram of the oxides of $\mathrm{Fe}, \mathrm{Cr}, \mathrm{Mn}$, and $\mathrm{Cu}[10]$

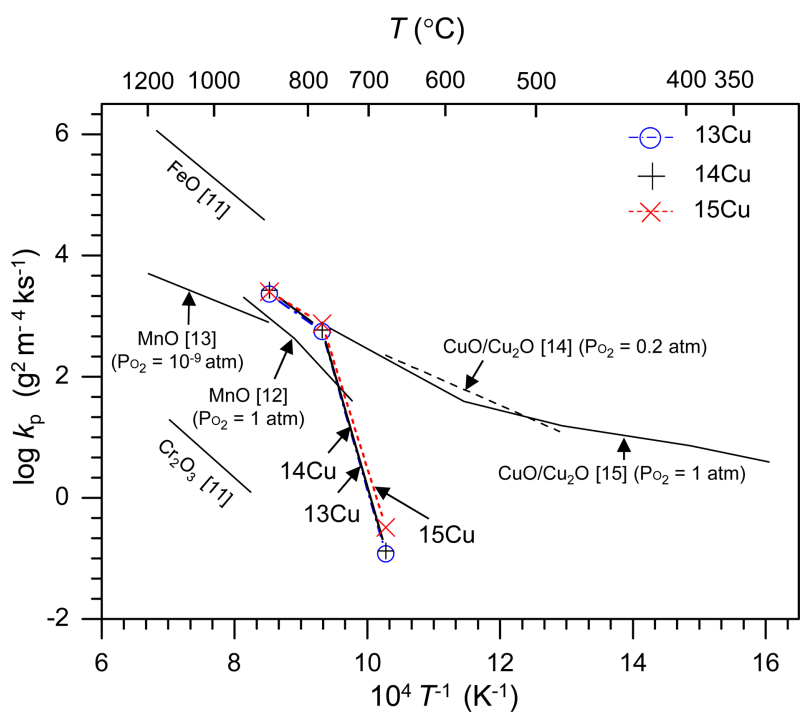

Fig. 4. Arrehnius plot of the parabolic rate constants for the growth of oxides of $\mathrm{Fe}$ [11], $\mathrm{Cr}$ [11], $\mathrm{Mn}[12,13]$, and $\mathrm{Cu}[14,15]$. Superimposed are $k_{\mathrm{p}}$ values of $\mathrm{Fe}-12 \mathrm{Cr}-0.3 \mathrm{C}-4 \mathrm{Mn}-(13,14,15) \mathrm{Cu}$ alloys at 700,800 , and $900{ }^{\circ} \mathrm{C}$

parabolic rate constants, $k_{\mathrm{p}}$, of Fe-12Cr-0.3C-4Mn-(13, 14, 15) $\mathrm{Cu}$ alloys were obtained using the equation, $\Delta \mathrm{W}^{2}=k_{\mathrm{p}} \bullet t$, where $\Delta \mathrm{W}$ is the weight gain per unit area and $t$ is the oxidation time. The Arrehnius plot shown in Fig. 4 indicates that the Fe-12Cr-0.3C-4Mn- $(13,14,15) \mathrm{Cu}$ alloys oxidized at almost similar rates at each temperature, and their oxidation rates increased sharply when the temperature increased from 700 to $800{ }^{\circ} \mathrm{C}$. The $k_{\mathrm{p}}$ value of the $15 \mathrm{Cu}$ alloy at $700{ }^{\circ} \mathrm{C}$ was evaluated for a period of $0-7 \mathrm{~h}$, while all other values were evaluated for the entire oxidation period. The $k_{\mathrm{p}}$ values of the pure metals decreased in the order of $\mathrm{Fe}[11], \mathrm{Mn}[12,13]$ or 
$\mathrm{Cu}[14,15]$, and $\mathrm{Cr}[11]$. The $k_{\mathrm{p}}$ values of the $\mathrm{Fe}-12 \mathrm{Cr}-0.3 \mathrm{C}$ $4 \mathrm{Mn}-(13,14,15) \mathrm{Cu}$ alloys were located between those of $\mathrm{Fe}$ and $\mathrm{Cr}$ (Fig. 4).

On the other hand, the deviation from stoichiometry, defined by $\delta$, ranges between $0.04-0.17$ for $\mathrm{Fe}_{1-\delta} \mathrm{O}$ [11,16], 00.06 for $\mathrm{Cu}_{2-\delta} \mathrm{O}$ [16], and $0-0.15$ for $\mathrm{Mn}_{1-\delta} \mathrm{O}[16,17]$. With such cation-vacancy concentrations, the mobilities of cations are high, resulting in the fast oxidation of $\mathrm{Fe}, \mathrm{Mn}$, and $\mathrm{Cu}$ compared to $\mathrm{Cr}$, which forms highly stoichiometric $\mathrm{Cr}_{2} \mathrm{O}_{3}$. The oxidation of $\mathrm{Fe}$ is mainly controlled by the outward diffusion of $\mathrm{Fe}^{2+}$ and $\mathrm{Fe}^{3+}$ ions, resulting in the formation of a triple-layered scale consisting of $\mathrm{FeO} / \mathrm{Fe}_{3} \mathrm{O}_{4} / \mathrm{Fe}_{2} \mathrm{O}_{3}$, with a thick FeO layer next to the metal [11].

Manganese is oxidized by the outward diffusion of $\mathrm{Mn}^{2+}$ ions through $\mathrm{MnO}[12,18]$. The oxidation of $\mathrm{Cu}$ results in the formation of an outer, thin $\mathrm{CuO}$ layer, and an inner, thick $\mathrm{Cu}_{2} \mathrm{O}$ layer [14,15]. Since $\mathrm{CuO}$ is an intrinsic semiconductor and $\mathrm{Cu}_{2} \mathrm{O}$ is the cation-deficient, nonstoichiometric oxide, the oxidation of $\mathrm{Cu}$ is mainly controlled by the outward diffusion of $\mathrm{Cu}$ ions through $\mathrm{Cu}_{2} \mathrm{O}[14,15]$. The outward diffusion of $\mathrm{Fe}, \mathrm{Mn}$, and $\mathrm{Cu}$ was observed during the oxidation of the $\mathrm{Fe}$ $12 \mathrm{Cr}-0.3 \mathrm{C}-4 \mathrm{Mn}-(13,14,15) \mathrm{Cu}$ alloys, as will be shown below.

Figure 5 shows the XRD/SEM/EPMA results of the Fe$12 \mathrm{Cr}-0.3 \mathrm{C}-4 \mathrm{Mn}-13 \mathrm{Cu}$ alloy after oxidation at $700{ }^{\circ} \mathrm{C}$ for 30 h. In Fig. 5(a), the $\mathrm{Cu}$ peaks are weaker than $\alpha$-Fe peaks, because there was a 10.3 vol\% secondary phase in the $(\mathrm{Fe}$, $\mathrm{Cr}$ )-rich matrix. The peaks of $\alpha-\mathrm{Fe}$ and $\mathrm{Cu}$ were stronger than those of $\mathrm{FeMnO}_{3}, \mathrm{Cu}_{2} \mathrm{O}$, and $\mathrm{CuO}$, indicating the small extent of oxidation. The secondary phase oxidized preferentially, while the $\alpha-F e$ matrix oxidized slightly, revealing the grinding grooves that formed during sample preparation (Fig. 5(b)). Manganese oxidizes rather easily (Fig. 3) and fast (Fig. 4), which helps the oxidation of the more noble but still rather fast oxidizing $\mathrm{Cu}$ in the secondary phase. This results in the nodular oxidation of the secondary phase (Figs. 5(c-d)). Iron oxidizes fast, but $\mathrm{Cr}$ oxidizes quite slowly (Fig. 4). This leads to the uniform oxidation of the (Fe, $\mathrm{Cr}$ )-rich matrix (Figs. 5(c-d)). Oxide nodules protruded from the initially flat sample surface because of the outward diffusion of $\mathrm{Fe}, \mathrm{Cu}$, and $\mathrm{Mn}$ (Figs. 5(b-d)), which accompanied the formation of voids in the oxide nodules (Fig. 5(c)). Manganese oxidized to stable $\mathrm{FeMnO}_{3}$ spinel (a)

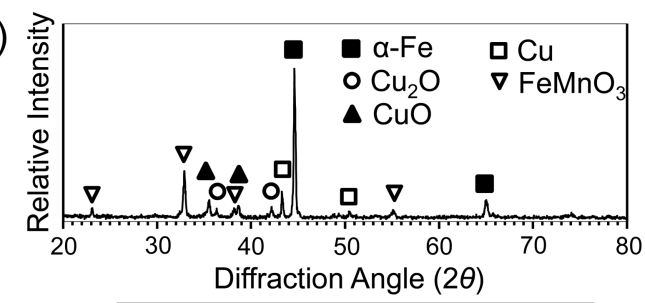

(b)

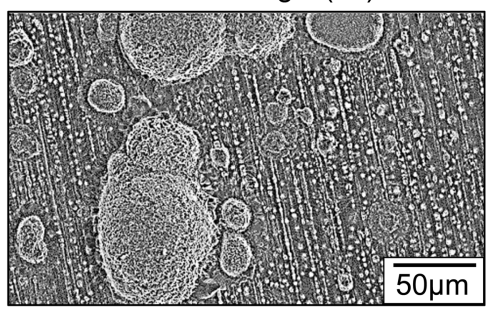

(c)

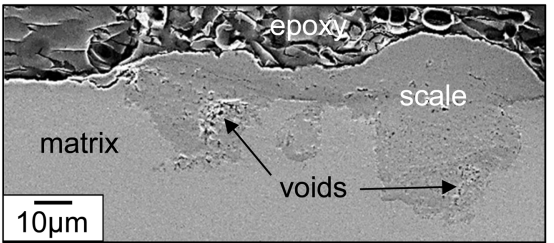

(d)

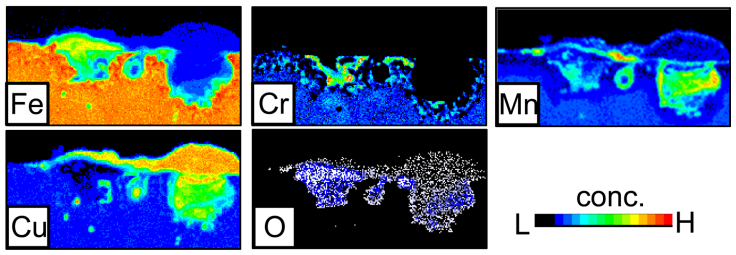

Fig. 5. Fe- $12 \mathrm{Cr}-0.3 \mathrm{C}-4 \mathrm{Mn}-13 \mathrm{Cu}$ alloy after oxidation at $700{ }^{\circ} \mathrm{C}$ for $30 \mathrm{~h}$. (a) XRD pattern, (b) SEM top view, (c) EPMA secondary electron (SE) cross-sectional image, (d) EPMA maps of (c)

(Fig. 5(a)). Copper oxidized to $\mathrm{Cu}_{2} \mathrm{O}$ and $\mathrm{CuO}$. Chromium, which forms highly stoichiometric, quite slowly growing $\mathrm{Cr}_{2} \mathrm{O}_{3}$, was primarily oxidized by the inwardly diffusing oxygen (Fig. 5(d)).

When the oxidation temperature was increased to $800{ }^{\circ} \mathrm{C}$, oxide nodules were no longer noticeable because not only the $(\mathrm{Cu}, \mathrm{Mn})$-rich secondary phase but also the (Fe, $\mathrm{Cr}$ )-rich matrix oxidized considerably, as shown in Figs. 6(a-b). Voids and cracks developed in the thick oxide scale owing to the outward diffusion of $\mathrm{Fe}, \mathrm{Cr}, \mathrm{Cu}$, and $\mathrm{Mn}$, anisotropic volume expansion, and stress generated during scaling. The PillingBedworth ratios are 1.78 for $\mathrm{Fe} / \mathrm{Fe}_{2} \mathrm{O}_{3}, 2.1$ for $\mathrm{Fe} / \mathrm{Fe}_{3} \mathrm{O}_{4}, 2.02$ for $\mathrm{Cr} / \mathrm{Cr}_{2} \mathrm{O}_{3}, 1.72$ for $\mathrm{Cu} / \mathrm{CuO}, 1.67$ for $\mathrm{Cu} / \mathrm{Cu}_{2} \mathrm{O}$, and 1.77 for $\mathrm{Mn} / \mathrm{MnO}$ [19]. The outer and inner oxide scale was about 95 and $85 \mu \mathrm{m}$-thick, respectively. The base element, Fe, diffused outward appreciably to form a Fe-rich outer oxide layer, which depleted $\mathrm{Fe}$ and thereby enriched $\mathrm{Cr}$ in the inner 

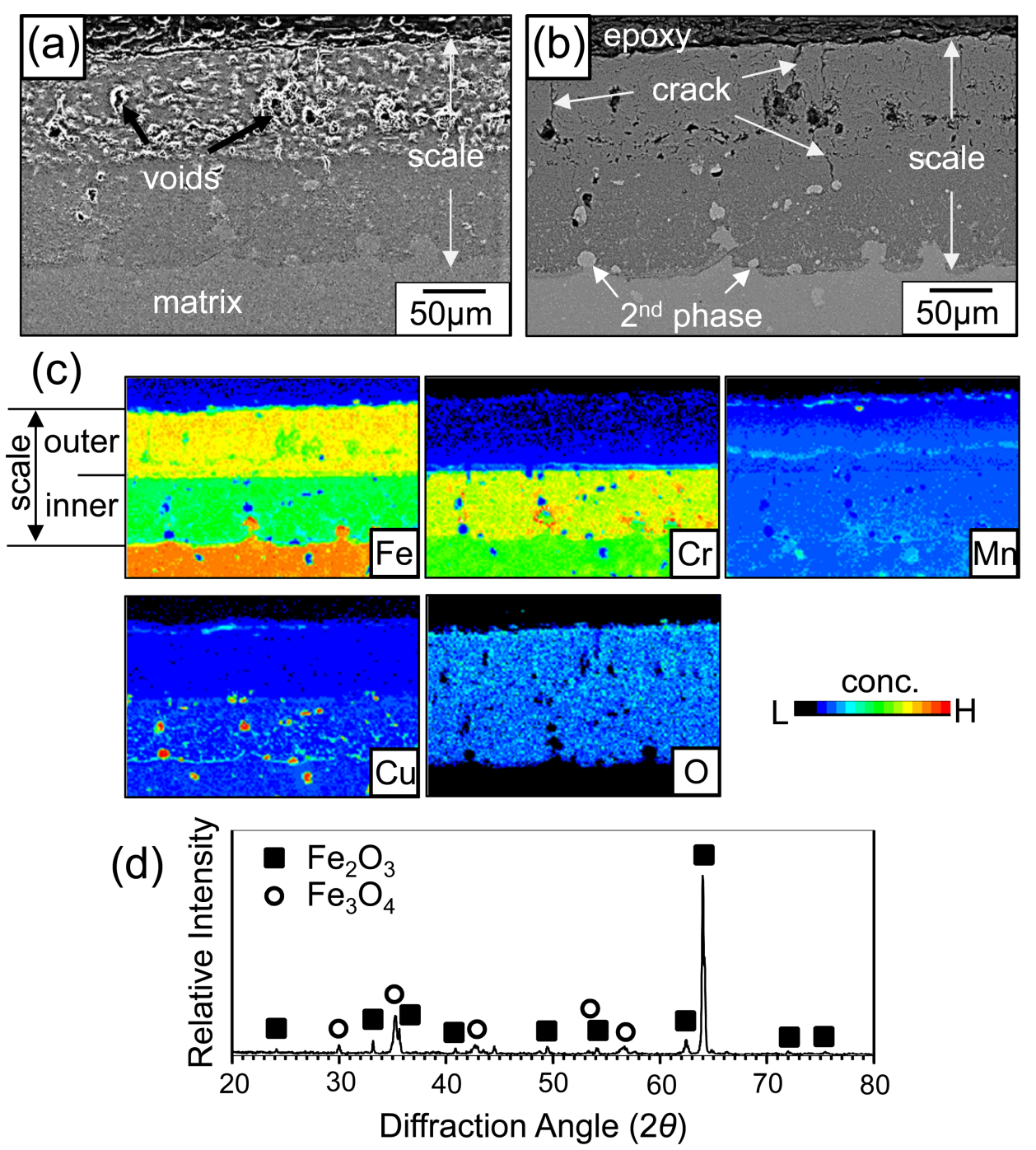

Fig. 6. Fe-12Cr-0.3C-4Mn-13Cu alloy after oxidation at $800{ }^{\circ} \mathrm{C}$ for $30 \mathrm{~h}$. (c) EPMA SE cross-sectional image, (b) EPMA backscattered electron (BSE) cross-sectional image, (c) EPMA maps of (a), (d) XRD pattern

oxide layer (Fig. 6(c)). The outer oxide scale consisted mainly of $\mathrm{Fe}_{2} \mathrm{O}_{3}$ and some $\mathrm{Fe}_{3} \mathrm{O}_{4}$, and was dissolved with $\mathrm{Cr}$, $\mathrm{Cu}$, and Mn (Figs. 6(c-d)). A small amount of the unoxidized secondary phase containing the most noble element, $\mathrm{Cu}$, was retained in the inner oxide scale, while that phase was unobservable in the outer oxide scale. Hence, it is suggested that the inner and outer oxide scale is formed by the inward diffusion of oxygen, and the outward diffusion of $\mathrm{Fe}, \mathrm{Cr}, \mathrm{Cu}$, and $\mathrm{Mn}$, respectively.

When the oxidation temperature was increased further to $900{ }^{\circ} \mathrm{C}$, a bi-layered, porous, fragile oxide scale formed, as shown in Figs. 7(a-b). The outer oxide scale with coarse voids was $220 \mu \mathrm{m}$-thick and Fe-rich, while the inner, dense oxide layer was $240 \mu \mathrm{m}$-thick and Cr-rich (Figs. 7(a-b)). Manganese diffused out faster than $\mathrm{Cu}$ from the secondary phase in the inner oxide scale (Fig. 7(b)). Again, it is seen that the outer oxide scale grew by the outward diffusion of $\mathrm{Fe}, \mathrm{Cr}, \mathrm{Cu}$, and $\mathrm{Mn}$, while the inner oxide scale grew by the inward diffusion of oxygen. Arrayed fine voids at the boundary of the outer and inner oxide scale resulted from the Kirkendall effect and the compositional difference between the outer and inner oxide scales (Fig. 7(a)). The outer oxide scale consisted mainly of $\mathrm{Fe}_{2} \mathrm{O}_{3}$ and some $\mathrm{MnFe}_{2} \mathrm{O}_{4}$ spinel that formed through the reaction of $\mathrm{Fe}_{2} \mathrm{O}_{3}$ with $\mathrm{MnO}$ (Fig. 7(c)). This result also confirmed that both $\mathrm{Mn}$ and $\mathrm{Fe}$ diffused up to the oxide surface considerably, while $\mathrm{Cr}$ 


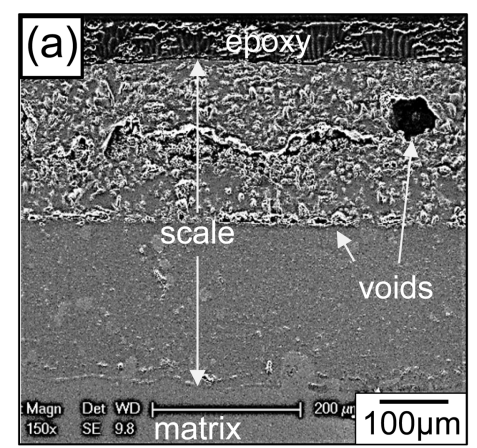

(b)

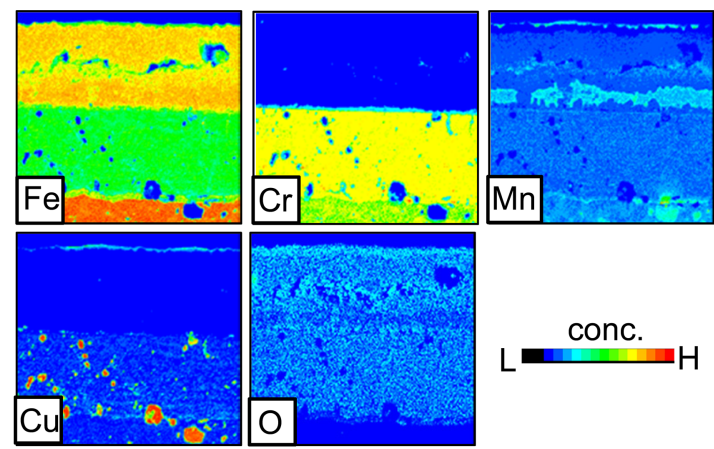

(c)

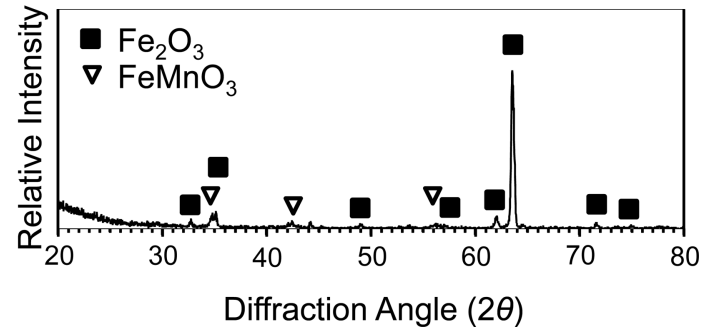

Fig. 7. Fe-12Cr-0.3C-4Mn-13Cu alloy after oxidation at $900{ }^{\circ} \mathrm{C}$ for 30 h. (a) EPMA SE cross-sectional image, (b) EPMA maps of (a), (c) XRD pattern

tended to reside in the inner oxide scale (Fig. 7(b)). The elemental distribution in the oxide scale depends on the concentration or activity, diffusivity, and oxygen affinity of the participating elements.

In order to study the oxides that formed in the initial stage, an XPS analysis was performed on Fe-12Cr-0.3C-4Mn-13Cu alloy after oxidation at $700{ }^{\circ} \mathrm{C}$ for $5 \mathrm{~h}$, as shown in Fig. 8 . The XPS-analyzed scale composition was $20.5 \mathrm{Fe}-15.9 \mathrm{Cu}-$ $2.7 \mathrm{Mn}-60.9 \mathrm{O}$ in at $\%$, indicating that the oxidation of $\mathrm{Fe}$ was suppressed to a certain extent by $\mathrm{Cr}$ in the matrix, while the $(\mathrm{Cu}, \mathrm{Mn})$-rich secondary phase oxidized appreciably. The spectra of $\mathrm{Fe}_{2 \mathrm{p} 3 / 2}, \mathrm{Cu}_{2 \mathrm{p} 3 / 2}$, and $\mathrm{Mn}_{2 \mathrm{p} 3 / 2}$ were centered at the binding energies of 710.6, 933.1, and $641 \mathrm{eV}$, respectively, which closely matches the binding energies of $\mathrm{Fe}_{2} \mathrm{O}_{3}$ (710.9 eV) [20], $\mathrm{CuO}(933.6 \mathrm{eV})$ [20], and $\mathrm{MnO}(640.3 \mathrm{eV})$ [21].

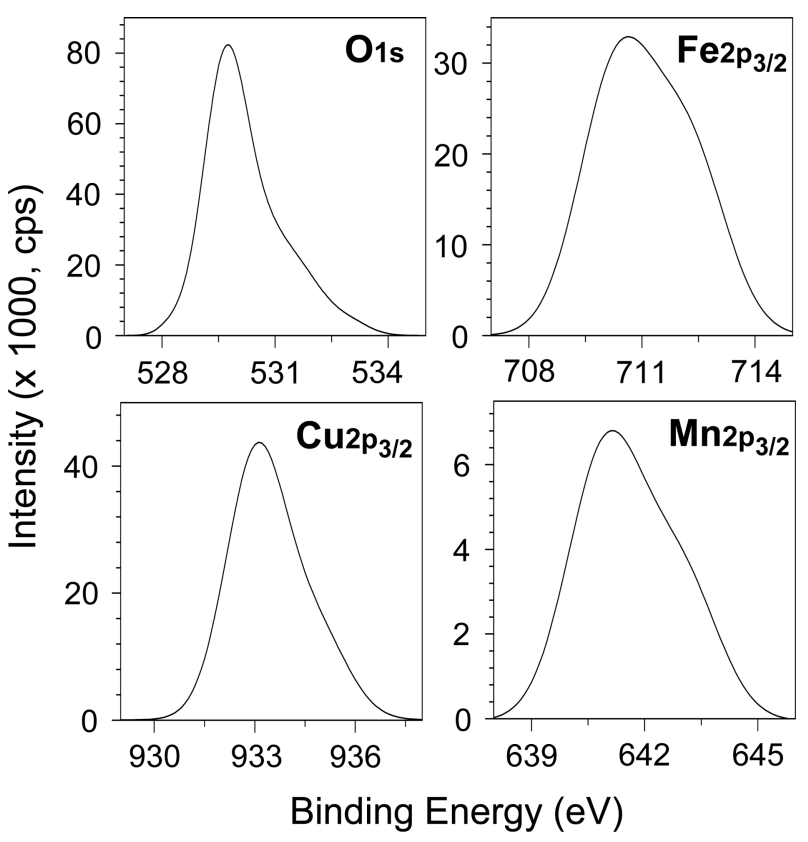

Fig. 8. XPS spectra of $\mathrm{Fe}-12 \mathrm{Cr}-0.3 \mathrm{C}-4 \mathrm{Mn}-13 \mathrm{Cu}$ alloy after oxidation at $700{ }^{\circ} \mathrm{C}$ for $5 \mathrm{~h}$

The small deviation in binding energies may be attributed to the dissolution of dissimilar cations in the formed oxides.

Results similar to Figs. 5-8 were also observed for the Fe$12 \mathrm{Cr}-0.3 \mathrm{C}-4 \mathrm{Mn}-(14,15) \mathrm{Cu}$ alloys, which indicates that all the alloys oxidized at similar rates, forming similar oxide scales.

\section{CONCLUSIONS}

Fe-12Cr-0.3C-4Mn-(13, 14, 15)Cu alloys consisting of an $(\mathrm{Fe}, \mathrm{Cr})$-rich matrix and a $(\mathrm{Cu}, \mathrm{Mn})$-rich secondary phase were prepared. They were oxidized at almost similar rates between $700-900{ }^{\circ} \mathrm{C}$. Their oxidation rates increased with increasing amounts of $\mathrm{Cu}$, and increased considerably more with increasing temperature. At $700{ }^{\circ} \mathrm{C}$, the $\alpha$-Fe matrix oxidized slower than the secondary phase because of highly oxidation-resistant chromium, leading to the formation of oxide nodules. At $800-900{ }^{\circ} \mathrm{C}$, the $\alpha$-Fe matrix also oxidized quickly, facilitating the formation of bi-layered oxide scales. The outer oxide scale grew by the outward diffusion of $\mathrm{Fe}$, $\mathrm{Cu}$, and $\mathrm{Mn}$, which facilitated the formation of voids in the inner oxide scale. The outward diffusion of $\mathrm{Cr}$ was weak. The inner oxide scale grew by the inward diffusion of oxygen. The alloys oxidized to $\mathrm{Fe}_{2} \mathrm{O}_{3}, \mathrm{Fe}_{3} \mathrm{O}_{4}, \mathrm{FeMnO}_{3}$, 
$\mathrm{MnFe}_{2} \mathrm{O}_{4}, \mathrm{MnO}, \mathrm{Cu}_{2} \mathrm{O}$, and $\mathrm{CuO}$. Since $\mathrm{Cr}$ was dissolved in those oxides, $\mathrm{Cr}_{2} \mathrm{O}_{3}$ was not detected.

\section{ACKNOWLEDGEMENT}

This work was supported by the project "Development of the High-Efficiency Low-Emission Future Energy Production Technology (EO15580)" of National Research Council of Science \& Technology (NST) grant by the Korea government (MSIP) (No. CRC-15-07-KIER).

\section{REFERENCES}

1. S. Zhu, J. Cheng, Z. Qiao, and J. Yang, Tribol. Int. 133, 206 (2019).

2. D. Xiang and K. Shan, Wear 260, 1112 (2006).

3. P. V. Muterlle, I. Cristofolini, M. Pilla, W. Pahl, and A. Molinari, Mater. Design 32, 3756 (2011).

4. V. Mamedov, Powder Metall. 47, 173 (2004).

5. M. Niu, X. Zhang, and J. Yang, Vacuum 154, 315 (2018)

6. K. N. Kim, B. S. Kim, G. S. Shin, M. C. Park, D. H. Lee, and S. J. Kim, Met. Mater. Int. 17, 587 (2011).

7. K. N. Kim, G. S. Shin, M. C. Park, S. Y. Lee, J. Y. Yun, and S. J. Kim, Korean J. Met. Mater. 50, 637 (2012).

8. Y. W. Cho, J. H. Won, J. H. Woo, S. H. Yu, and Y. R. Cho, Korean J. Met. Mater. 56, 289 (2018).
9. J. Jung, J. J. Oak, Y. H. Kim, Y. J. Cho, and Y. H. Park, Met. Mater. Int. 23, 1097 (2017).

10. I. Barin, Thermochemical Data of Pure Substances, VCH, Germany (1989).

11. N. Birks, G. H. Meier, and F. S. Pettit, Introduction to the High Temperature Oxidation of Metals, 2nd edn, Cambridge University Press, England (2006).

12. F. Gesmundo, P. Nanni, and D. P. Whittle, Corros. Sci. 19, 675 (1979).

13. S. Mrowec and K. Przybylski, Oxid. Met. 23, 107 (1985).

14. J. P. Wang and W. D. Cho, ISIJ Int. 49, 1926 (2009).

15. Y. Zhu, K. Mimura, and M. Isshiki, Mater. Trans. 43, 2173 (2002).

16. T. B. Reed, The Chemistry of Extended Defects in NonMetallic Solids, L. Eyring and M. O'Keeffe, eds., NorthHolland, Amsterdam (1970).

17. P. Kofstad, Solid State Ionics 12, 101 (1984).

18. K. Fueki and J. B. Wagner, J. Electrochem. Soc. 112, 970 (1965).

19. A. S. Khanna, Introduction to High Temperature Oxidation and Corrosion, p.80, ASM International, USA (2002).

20. J. F. Moulder, W. F. Stickle, P. E. Sobol, and K. D. Bomben, Handbook of X-ray Photoelectron Spectroscopy, Physical Electronics, Inc., USA (1995).

21. M. C. Biesinger, B. P. Payne, A. P. Grosvenor, L. W. M. Lau, A. R. Gerson, and R. St.C. Smart, Appl. Surf. Sci. 257, 2717 (2011). 